\title{
PENGARUH KUALITAS PRODUK DAN PROMOSI TERHADAP KEPUTUSAN PEMBELIAN GOLDEN FARM FRENCH FRIES PADA PT SUKANDA DJAYA MEDAN
}

\author{
Melva M Sitompul \\ Fakultas Ekonomi, STIE Akuntansi dan Bisnis Internasional \\ melva.melany@yahoo.co.id
}

\begin{abstract}
Marketing activities in the company are the main thing in keeping the company able to provide products in accordance with customer expectations. The company's ability to provide products that meet customers expectations will certainly be a value for customers in giving trust to the company and continuously buying these products.This of course will also make the income owned by the company able to increase.Purchasing decisions are decisions that are given determining which product to choose and to buy.Purchasing decisions are important when the company is able to maintain customer confidence properly, it will create repeat purchases from consumers which of course will make profits for the company.Product quality is a product's ability to meet consumer expactations. High product quality will give a good impression to consumers when consuming these products. All consumers expect good quality when buying a product. Product quality factors are closely related to consumer choice. Promotion is an activity to introduce the features of product to cunsumers.Promotion is very important in managing and supporting companies in selling the products they have. With the promotion the company will be better able to introduce products to consumers in the company.
\end{abstract}

Keywords : Product quality, Promotion, Purchase decision

\section{PENDAHULUAN}

\section{Latar Belakang}

Kegiatan pemasaran di perusahaan menjadi hal yang utama dalam menjaga perusahaan untuk tetap mampu memberikan produk yang sesuai dengan harapan pelanggan. Kemampuan perusahaan dalam memberikan produk yang sesuai harapan pelanggan tentu akan menjadi sebuah nilai bagi pelanggan dalam memberikan kepercayaan kepada perusahaan dan terus menerus membeli produk tersebut. Hal ini tentu juga akan membuat pendapatan yang dimiliki oleh perusahaan mampu meningkat dan naik.Keputusan pembelian merupakan keputusan yang diberikan dalam menentukan produk yang dipilih dan akan dibeli. Keputusan pembelian menjadi penting ketika perusahaan mampu menjaga kepercayaan konsumen dengan baik, maka akan tercipta pembelian berulang dari konsumen yang tentu saja akan membuat keuntungan bagi perusahaan.

Kualitas produk adalah kemampuan produk dalam memenuhi harapan konsumen. Kualitas produk yang tinggi akan memberi sebuah kesan baik bagi konsumen ketika melakukan konsumsi produk tersebut. Kualitas yang baik tentu akan diharapkan oleh semua konsumen dalam membeli sebuah produk. Faktor kualitas produk sangat berkaitan dengan pilihan konsumen.

Promosi adalah kegiatan memperkenalkan fitur-fitur yang dimiliki oleh suatu produk kepada konsumen.Promosi sangat penting dalam mengatur dan mendukung perusahaan di dalam menjual produk 
yang mereka miliki. Dengan adanya promosi maka perusahaan akan lebih mampu memperkenalkan produk dengan baik kepada konsumen di perusahaan. Dengan dikenalnya produk oleh konsumen maka perusahaan tidak akan kesulitan dalam menjual produk karena konsumen sudah mengenal sebelumnya melalui media promosi.PT Sukanda Djaya Medan adalah salah satu perusahaan yang bergerak di bidang distributor makanan cepat saji.Salah satu produk yang dijual oleh perusahaan adalah Golden Farm French Fries (Kentang Goreng). Pada saat ini terjadi penurunan keputusan di perusahaan yang terlihat dari tidak tercapainya target penjualan perusahaan. Berikut data penjualan perusahaan.

Tabel . 1

Data Penjualan Perusahaan

\begin{tabular}{|c|c|c|c|}
\hline Bulan & $\begin{array}{c}\text { Target Penjualan } \\
\text { (Rupiah) }\end{array}$ & $\begin{array}{c}\text { Jumlah Penjualan } \\
\text { (Rupiah) }\end{array}$ & Persentase \\
\hline Januari & $500,000,000$ & $415,000,000$ & $83 \%$ \\
\hline Februari & $500,000,000$ & $411,250,000$ & $82 \%$ \\
\hline Maret & $500,000,000$ & $405,000,000$ & $81 \%$ \\
\hline April & $500,000,000$ & $402,500,000$ & $81 \%$ \\
\hline Mei & $500,000,000$ & $400,250,000$ & $80 \%$ \\
\hline Juni & $500,000,000$ & $395,750,000$ & $79 \%$ \\
\hline Juli & $500,000,000$ & $323,250,000$ & $65 \%$ \\
\hline Agustus & $500,000,000$ & $321,500,000$ & $64 \%$ \\
\hline September & $500,000,000$ & $322,500,000$ & $65 \%$ \\
\hline Oktober & $500,000,000$ & $318,000,000$ & $64 \%$ \\
\hline November & $500,000,000$ & $312,000,000$ & $62 \%$ \\
\hline Desember & $500,000,000$ & $314,750,000$ & $63 \%$ \\
\hline
\end{tabular}

Sumber : PT Sukanda Djaya Medan

Dari data penjualan terlihat bahwa jumlah penjualan perusahaan untuk produk Golden Farm French Fries belum mampu dalam mencapai target yang diinginkan oleh perusahaan. Pencapaian tertinggi hanya terjadi di bulan Januari dengan persentase $83 \%$ dan pencapaian terendah terjadi di bulan November dengan persentase $62 \%$. Ketidakmampuan perusahaan dalam mencapai target penjualan memperlihatkan bahwa keputusan pembelian di perusahaan telah mengalami penurunan. Penurunan yang cukup banyak terjadi dikarenakan banyak produk baru yang mempersulit peningkatan penjualan perusahaan. 
Tabel . 2

Data Kegiatan Promosi Perusahaan

\begin{tabular}{|c|c|c|c|}
\hline Jenis Kegiatan & Media & Frekuensi/ Tahun & Permasalahan \\
\hline $\begin{array}{l}\text { Personal } \\
\text { Selling }\end{array}$ & $\begin{array}{l}\text { Kunjungan personal salesman ke } \\
\text { supermarket untuk menawarkan } \\
\text { produk }\end{array}$ & 2 bulan sekali & $\begin{array}{l}\text { Kunjungan personal yang kurang maksimal } \\
\text { kemampuan salesman di dalam menjelaskan } \\
\text { keunggulan produk dengan baik }\end{array}$ \\
\hline Pameran & $\begin{array}{l}\text { Mengadakam kegiatan pameran } \\
\text { produk bersama dengan supplier } \\
\text { lain di food show dan } \\
\text { menempatkan sales prinsipal di } \\
\text { supermarket untuk menarik } \\
\text { pelanggan }\end{array}$ & 1 bulan sekali & $\begin{array}{l}\text { Kegiatan pameran kurang efektif dikarenakan } \\
\text { hanya melakukan join pameran dengan } \\
\text { supplier lain tanpa membuat pameran khusus } \\
\text { sendiri dengan jangka waktu pameran yang } \\
\text { terlalu lama hingga } 1 \text { bulan sekali }\end{array}$ \\
\hline $\begin{array}{c}\text { Sales } \\
\text { Promotion }\end{array}$ & $\begin{array}{l}\text { Membuat pemberian sampel } \\
\text { produk secara gratis kepada } \\
\text { pelanggan, hadiah pembelian } \\
\text { kepada pelanggan, pemberian } \\
\text { potongan harga, dan penawaran } \\
\text { kontrak pembelian }\end{array}$ & 1 bulan sekali & $\begin{array}{l}\text { Pemberian sampel produk, hadiah, potongan } \\
\text { harga pembelian dan penawaran kontrak } \\
\text { pembelian untuk durasi jangka panjang yang } \\
\text { jarang dilakukan }\end{array}$ \\
\hline Advertising & $\begin{array}{l}\text { Iklan melalui media sosial dan } \\
\text { pembagian brosur }\end{array}$ & 3 bulan sekali & 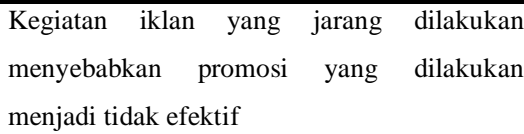 \\
\hline
\end{tabular}

Sumber : PT Sukanda Djaya Medan

Dari data kegiatan promosi perusahaan, terlihat bahwa jumlah promosi yang dilakukan oleh perusahaan cukup sedikit. Jadwal kegiatan promosi yang sedikit tentu akan membuat sebuah kesulitan bagi perusahaan dalam memperkenalkan produk lebih luas kepada pelanggan. Promosi yang tidak dilakukan dengan rutin tentu akan menjadi sebuah masalah dalam memperluas jaringan pemasaran di perusahaan.

\section{Rumusan Masalah}

Berdasarkan pembahasan masalah yang telah diuraikan, maka peneliti bermaksud untuk melakukan penelitian dengan judul "Pengaruh Kualitas Produk dan Promosi Terhadap Keputusan Pembelian Golden Farm French Fries Pada PT Sukanda Djaya Medan”.Berdasarkan latar belakang yang telah diuraikan di atas, dapat dibuat identifikasi masalah pada penelitian ini, yaitu: Kualitas produk yang kurang baik terlihat dari jumlah retur yang terjadi setiap bulan memperlihatkan bahwa kualitas produk Golden Farm French Fries masih tidak mampu memenuhi konsumen.

\section{KAJIAN LITERATUR}

\section{Pengertian Kualitas Produk}

Menurut (Sangadji dan Sopiah, 2013) kualitas produk (product quality) didefinisikan sebagai evaluasi menyeluruh pelanggan atas kebaikan kinerja barang atau jasa.Menurut (Tjiptono dan Chandra, 2012), kualitas bisa diartikan sebagai produk yang bebas cacat.Menurut (Kotler dan Amstrong, 2008), kualitas produk berarti 
kualitas kinerja kemampuan produk untuk melaksanakan fungsinya.Berdasarkan pengertian di atas, kualitas produk adalah suatu bentuk kualitas yang dimiliki oleh sebuah produk dalam rangka memenuhi kebutuhan pasar. Kualitas produk sangat diperlukan dalam rangka mendukung penjualan produk ataupun jasa agar dapat bernilai lebih tinggi.

\section{Faktor-Faktor yang Mempengaruhi Kualitas Produk}

Menurut (Sunyoto, 2014) kualitas produk dapat ditentukan oleh :

1. Material

Bahan-bahan yang diperlukan dalam rangka membuat produk.

2. Teknik atau cara pembuatan

Teknik dan cara pembuatan produk menentukan kualitas produk.

3. Tingkat keahlian orang atau perusahaan yang mengerjakan

Tingkat keahlian orang yang membuat juga menentukan detail dan hasil kualitas produk.

4. Engineering design dan specifications

Spesifikasi produk yang telah dibuat juga menentukan kualitas produk

5. Daya tarik

Daya tarik visual produk juga menentukan kualitas suatu produk.

\section{Indikator Kualitas Produk}

Menurut (Abdullah dan Tantri , 2013) indikator kualitas produk adalah sebagai berikut :

1. Keawetan

Daya tahan suatu produk juga akan menentukan kualitas dari produk tersebut.

2. Keandalan

Keunggulan suatu produk akan ditentukan oleh kualitas produk tersebut.

3. Ketepatan

Ketepatan sasaran produk juga menunjukkan bahwa kualitas yang dimiliki sudah baik.

4. Kemudahan dipergunakan dan diperbaiki

Mudahnya pengunaan dan perbaikan produk juga memperlihatkan kualitas dari sebuah produk.

5. Atribut yang bernilai lain

Produk yang bisa dijual dan ditukar dengan barang lain memperlihatkan jumlah harga suatu produk.

\section{Arti Penting Promosi}

Menurut (Rangkuti, 2009), promosi merupakan kegiatan paling penting untuk meningkatkan revenue. Tanpa kegiatan promosi, perusahaan tidak dapat memperoleh pelanggan sesuai yang diharapkan.promosi merupakan fungsi pemasaran yang fokus untuk mengkomunikasikan program-program pemasaran secara persuasif kepada target pelanggan atau calon pelanggan untuk mendorong terciptanya transaksi pertukaran antara perusahaan dan pelanggan. 
Menurut (Tjiptono, 2015), promosi merupakam elemen bauran pemasaran yang berfocus pada upaya menginformasikan, membujuk, dan mengigatkan kembali konsumen akan merek dan produk perusahaan.

Berdasarkan pengertian di atas, promosi merupakan salah satu elemen penting dalam pemasaran untuk memperkenalkan keunggulan suatu produk kepada konsumen.

\section{Manfaat dan Tujuan Promosi}

Menurut (Hasan, 2013) manfaat promosi, antara lain :

1. Menciptakan atau meningkatkan awareness produk atau brand

2. Meningkatkan preferensi brand pada target pasar

3. Meningkatkan penjualan dan market share

4. Mendorong pembelian ulang merek yang sama

5. Memperkenalkan produk baru

6. Menarik pelanggan baru

Menurut (Manap, 2016), tujuan promosi ialah memperoleh perhatian, mendidik, mengingatkan, dan meyakinkan calon konsumen.

\section{Indikator Promosi}

Menurut (Hasan, 2013) indikator promosi adalah sebagai berikut :

1. Periklanan

Adalah bentuk kegiatan promosi seperti pembagian brosur, pemotongan harga dan bentuk lainnya.

2. Pemasaran Langsung

Adalah bentuk kegiatan promosi yang melakukan penjualan langsung ke lapangan kepada pelanggan.

3. Selling

\section{Teori Keputusan Pembelian}

\section{Arti Penting Keputusan Pembelian}

Menurut (Sangadji dan Sopiah, 2013) "Pengambilan keputusan konsumen adalah proses pemecahan masalah yang diarahkan pada sasaran. Pemecahan masalah konsumen sebenarnya merupakan suatu aliran tindakan timbal balik yang berkesinambungan."

Menurut (Hasan, 2013), setelah alternatif dievaluasi, konsumen siap untuk membuat keputusan pembelian. Kadang - kadang niat beli tidak mengakibatkan pembelian aktual. Marketer harus memfasilitasi konsumen untuk bertindak pada niat pembelian mereka.

Menurut (Abdullah dan Tantri, 2015), konsumen mempunyai perilaku pembelian kompleks jika mereka sangat terlibat dalam suatu pembelian dan menyadari adanya perbedaan signifikan antara berbagai merek. Konsumen sangat terlibat bila suatu produk mahal, jarang dibeli, berisiko, dan mempunya ekspresi pribadi yang tinggi. 


\section{Faktor - Faktor Yang Mempengaruhi Keputusan Pembelian}

Menurut (Hasan, 2013), keputusan pembelian konsumen dipengaruhi oleh tiga faktor, yaitu:

1. Faktor psikologis

Faktor psikologis mencakup persepsi, motivasi, pembelajaran, sikap, dan kepribadian.

2. Faktor situasional

Faktor situasional mencakup keadaan sarana dan prasarana tempat belanja, waktu berbelanja, penggunaan produk, dan kondisi saat pembelian.

3. Faktor sosial

Faktor sosial mencakup undang-undang atau peraturan, keluarga, kelompok referensi, kelas social, dan budaya.

\section{Hipotesis Penelitian}

Berdasarkan kerangka konseptual yang telah diuraikan diatas, maka hipotesis penelitian ini adalah:

1 Kualitas Produk berpengaruh terhadap Keputusan pembelian Golden Farm French Fries Pada PT. Sukanda Djaya Medan.

2 Promosi berpengaruh terhadap Keputusan pembelian Golden Farm French Fries Pada PT. Sukanda Djaya Medan.

3 Kualitas Produk dan Promosi berpengaruh terhadap Keputusan pembelian Golden Farm French Fries Pada PT. Sukanda Djaya Medan.

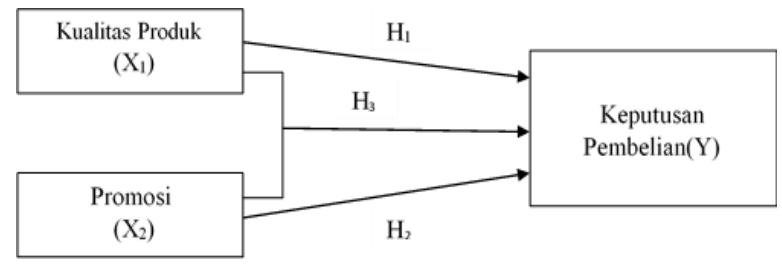

Kerangka Konseptual

\section{METODE}

\section{Jenis Penelitian}

Jenis penelitian ini merupakan jenis penelitian deskriptif kuantitatif. "Jenis penelitian deskriptif adalah penelitian yang dimaksudkan untuk menyelidiki keadaan, kondisi atau hal lain-lain yang sudah disebutkan, yang hasilnya dipaparkan dalam bentuk laporan penelitian"."Pendekatan kuantitatif adalah pendekatan yang didasarkan pada data yang dihitung untuk menghasilkan penafsiran yang kokoh". 


\section{Sifat Penelitian}

Sifat penelitian ini adalah deskriptif explanatory. Menurut (Zulganef, 2008), "Penelitian explanatory adalah penelitian yang bertujuan menelaah kausalitas antar variabel yang menjelaskan suatu fenomena tertentu”. Dalam penelitian explanatory peneliti berusaha untuk menjelaskan atau membuktikan hubungan atau pengaruh antar variabel.

\section{Populasi}

Menurut (Sugiyono, 2012) "Populasi adalah wilayah generalisasi yang terdiri dari objek/subjek yang mempunyai kualitas dan karakteristik tertentu yang ditetapkan oleh peneliti untuk dipelajari dan kemudian ditarik kesimpulannya". Penelitian ini memiliki populasi yaitu seluruh konsumen PT. Sukanda Djaya Medan yang berjumlah 163 pelanggan yang diambil secara acak dari bulan Juli 2017 - Desember 2017 dengan pengambilan minimal 130 bungkus.

Tabel.3

Jumlah Pelanggan Pada Bulan Juli - Desember 2017

\begin{tabular}{|l|l|l|}
\hline No & Bulan & $\begin{array}{l}\text { Jumlah Pelanggan Yang } \\
\text { Melakukan Pembelian }\end{array}$ \\
\hline 1 & Juli 2017 & 30 \\
\hline 2 & Agustus 2017 & 31 \\
\hline 3 & September 2017 & 29 \\
\hline 4 & Oktober 2017 & 35 \\
\hline 5 & November 2017 & 32 \\
\hline 6 & Desember 2017 & 31 \\
\hline \multicolumn{2}{|l|}{ Total } & $\mathbf{1 8 8}$ \\
\hline
\end{tabular}

Sumber : PT Sukanda Djaya Medan, 2017

\section{Sampel}

Menurut (Sugiyono, 2012), sampel adalah bagian dari jumlah dan karakteristik yang dimiliki oleh populasi tersebut. Sehingga sampel merupakan bagian dari populasi yang ingin diteliti dan dimaksudkan untuk dapat mewakili populasi penelitian. Teknik pengambilan sampling menggunakan simple random sampling dengan rumus Slovin. Rumus Slovin adalah sebagai berikut:

$$
n=\frac{N}{1+N e^{2}}
$$

Di mana :

$\mathrm{n}=$ ukuran sampel

$\mathrm{N}=$ ukuran populasi

$\mathrm{e}=$ persen kelonggaran karena kesalahan pengambilan sampel yang masih dapat ditolerir $(5 \%)$ 
Dengan populasi sebanyak 188 pelanggan dan tingkat kesalahan (e) sebesar 5\%, maka sampel (n) penelitian ini adalah :

$$
\mathrm{n}=\frac{188}{1+188(0,05)^{2}}=127,89 \text { atau } 128 \text { (hasil pembulatan) }
$$

Jadi sampel penelitian ini adalah sebanyak 128 toko, dimana 30 toko diambil dari sisa populasi sebagai sampel uji validitas dan realibilitas, sedangkan 128 toko diambil untuk pengujian sampel penelitian.

\section{Uji Validitas}

Menurut (Ghozali, 2013) uji validitas digunakan untuk mengukur sah atau valid tidaknya suatu kuesioner. Suatu kuesioner dikatakan valid jika pertanyaan pada kuesioner mampu untuk mengungkapkan sesuatu yang akan diukur oleh kuesioner tersebut. Uji signifikansi dilakukan dengan membandingkan nilai $r$ hitung dengan $\mathrm{r}$ tabel untuk degree of freedom $(\mathrm{df})=\mathrm{n}-2$, dalam hal ini $\mathrm{n}$ adalah jumlah sampel. Apabila $\mathrm{r}$ hitung lebih besar dari $r$ tabel maka suatu kuesioner dikatakan valid sebaliknya apabila $r$ hitung lebih kecil dari $r$ tabel maka suatu kuesioner dikatakan tidak valid.

Besarnya nilai $r$ tabel pada degree of freedom $(\mathrm{df})=\mathrm{n}-2=30-2=28$ dengan menggunakan uji signifikansi 2 arah sebesar 0,361 sehingga :

1. Jika $r$ hitung $>0,361$ maka item pertanyaan dikatakan valid

2. Jika $r$ hitung $<0,361$ maka item pertanyaan dikatakan tidak valid

\section{Uji Reliabilitas}

Menurut (Priyatno, 2013), suatu alat pengukur dikatakan reliable bila alat itu dalam mengukur suatu gejala pada waktu yang berlainan senantiasa menunjukkan hasil yang sama. Jadi alat yang reliable secara konsisten memberi hasil ukuran yang sama. Metode uji reliabilitas yang sering digunakan adalah Cronbach's Alpha.Menurut Sekaran dalam (Priyatno, 2013) pengambilan keputusan untuk uji reliabilitas sebagai berikut:

1. Cronbach's alpha $<0,6=$ reliabilitas buruk.

2. Cronbach's alpha $0,6-0,79=$ reliabilitas diterima.

3. Cronbach's alpha $0,8=$ reliabilitas baik.

\section{Model Analisis Data Penelitian}

Model analisis data dalam penelitian ini merupakan regresi berganda (multiple regression). Untuk mengetahui seberapa besar pengaruh kualitas produk dan promosi terhadap Keputusan Pembelian pada PT Sukanda Djaya Medan, dapat dihitung dengan bantuan perangkat lunak Statistical Product and Service Solution (SPSS) dengan rumus regresi berganda:

$\mathbf{Y}=\boldsymbol{\alpha}+\mathrm{b} 1 \mathrm{X} 1+\mathrm{b} 2 \mathrm{X} 2+\mathrm{e}$ 
Keterangan: $\quad \mathrm{Y}=$ Keputusan Pembelian (dependent variabel).

$\mathrm{X}_{1}=$ Kualitas Produk (independent variabel).

$\mathrm{X}_{2}=$ Promosi (independent variabel).

$\mathrm{a}=$ konstanta.

$\mathrm{b}_{1}=$ koefisien untuk variabel Promosi

$\mathrm{b}_{2}=$ koefisien untuk variabel Kualitas Produk

$\mathrm{e}=$ persentase kesalahan $(5 \%)$.

\section{HASIL DAN DISKUSI}

\section{Pembahasan}

Model analisis data yang digunakan untuk menjawab hipotesis penelitian adalah regresi linier berganda (multiple linier regression). Untuk mengetahui pengaruh variabel bebas dan variabel terikat digunakan rumus analisis linier berganda dimana rumus tersebut adalah sebagai berikut :

Tabel . 4

\section{Hasil Uji Regresi Linier Berganda}

\section{Coefficients $^{\mathrm{a}}$}

\begin{tabular}{|c|c|c|c|c|c|c|}
\hline \multirow{2}{*}{\multicolumn{2}{|c|}{ Model }} & \multicolumn{2}{|c|}{ Unstandardized Coefficients } & \multirow{2}{*}{ 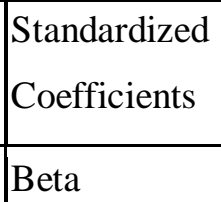 } & \multirow[b]{2}{*}{$\mathrm{t}$} & \multirow[b]{2}{*}{ Sig. } \\
\hline & & B & Std. Error & & & \\
\hline \multirow[t]{3}{*}{1} & (Constant) & 5.643 & 3.312 & & 1.704 & .091 \\
\hline & Kualitas Produk & .641 & .071 & .638 & 8.962 & .000 \\
\hline & Promosi & .331 & .119 & 197 & 2.773 & .006 \\
\hline
\end{tabular}

a. Dependent Variable: Keputusan Pembelian

Sumber: Hasil Penelitian, 2018 (data diolah)

Berdasarkan Tabel IV.1 maka persamaan regresi linier berganda dalam penelitian ini sebagai berikut : Keputusan Pembelian $=5.643+0.641$ Kualitas Produk +0.331 Promosi

1. Nilai konstanta a sebesar 5.643 artinya bahwa jika tidak terdapat variabel kualitas produk $\left(\mathrm{X}_{1}\right)$ dan promosi $\left(\mathrm{X}_{2}\right)=0$ maka keputusan pembelian akan bernilai sebesar 5.643 satuan.

2. Variabel kualitas produk $\left(\mathrm{X}_{1}\right)$ sebesar 0.641 yang artinya bahwa setiap kenaikan variabel kualitas produk sebesar 1 satuan, maka nilai pada keputusan pembelian akan naik 0.641 satuan dengan asumsi bahwa variabel yang lain tetap. 
3. Variabel promosi $\left(\mathrm{X}_{2}\right)$ sebesar 0.331 yang artinya bahwa setiap kenaikan variabel promosi sebesar 1 satuan, maka nilai pada keputusan pembelian akan naik 0.331 satuan dengan asumsi bahwa variabel yang lain tetap.

\section{Koefisien Determinasi $\left(\mathbf{R}^{2}\right)$}

Model analisis data dalam penelitian ini merupakan regresi berganda (multiple regression). Untuk mengetahui seberapa besar pengaruh kualitas produk dan promosi terhadap Keputusan Pembelian pada PT Sukanda Djaya Medan, dapat dihitung dengan bantuan perangkat lunak Statistical Product and Service Solution (SPSS) dengan rumus regresi berganda

Tabel. 5

Nilai Koefisien Determinasi (R Square) Model Summary

\begin{tabular}{|c|c|c|c|c|}
\hline Model & $\mathrm{R}$ & R Square & $\begin{array}{c}\text { Adjusted R } \\
\text { Square }\end{array}$ & $\begin{array}{c}\text { Std. Error of } \\
\text { the Estimate }\end{array}$ \\
\hline 1 & $.628^{\mathrm{a}}$ & .394 & .384 & 6.07267 \\
\hline
\end{tabular}

a. Predictors: (Constant), Promosi, Kualitas Produk

b. Dependent Variable: Keputusan Pembelian

Sumber: Hasil Penelitian, 2018 (data diolah)

Berdasarkan Tabel IV.2, nilai Adjusted $R$ Square adalah 0,384 artinya bahwa kemampuan variasi variabel kualitas produk $\left(\mathrm{X}_{1}\right)$ dan promosi $\left(\mathrm{X}_{2}\right)$ dalam menjelaskan variasi dari keputusan pembelian $(\mathrm{Y})$ adalah sebesar $38.4 \%$ dan sisanya sebesar $61.6 \%$ dijelaskan oleh variabel-variabel independen yang tidak diteliti seperti harga, kualitas pelayanan dan citra merek.

\section{Pengujian Hipotesis Secara Simultan (Uji-F)}

Pengujian hipotesis yang digunakan dalam penelitian adalah dengan menggunakan analisis regresi linier berganda. Model regresi yang digunakan adalah sebagai berikut : 
Tabel . 6

\section{Hasil Uji F}

\section{ANOVA $^{\text {b }}$}

\begin{tabular}{|cc|c|c|c|c|c|}
\hline \multicolumn{2}{|c|}{ Model } & Sum of Squares & $\mathrm{df}$ & Mean Square & $\mathrm{F}$ & Sig. \\
\hline 1 & Regression & 2994.204 & 2 & 1497.102 & 40.597 & $.000^{\mathrm{a}}$ \\
& Residual & 4609.671 & 125 & 36.877 & & \\
Total & 7603.875 & 127 & & & \\
& & & & & \\
\hline
\end{tabular}

a. Predictors: (Constant), Promosi, Kualitas Produk

b. Dependent Variable: Keputusan Pembelian

Sumber: Hasil Penelitian, 2018 (data diolah)

Pada Tabel IV.3, diperoleh hasil $\mathrm{F}_{\text {Hitung }} 40.597$ sedangkan $\mathrm{F}_{\text {tabel }}$ pada $\alpha=0,05$ diperoleh dari sumber probabilitas $\mathrm{F}_{\text {tabel }}$ yang tersedia pada jumlah sampel 128-3 =125 yaitu 3,08 yang dilihat dari tabel probabilitas $\mathrm{F}$ dari hasil ini diketahui $\mathrm{F}_{\text {hitung }}>\mathrm{F}_{\text {tabel, }}$ dan signifikansi 0,000 atau lebih kecil dari a $=0,05$ jadi posisi titik uji signifikansi berada pada wilayah penolakan $\mathrm{H}_{0}$ atau dapat disimpulkan $\mathrm{H}_{\mathrm{a}}$ diterima yang artinya bahwa variabel kualitas produk dan promosi secara bersama-sama berpengaruh positif dan signifikan terhadap variabel keputusan pembelian.

\section{Pengujian Hipotesis Secara Parsial (Uji t)}

Menurut (Ghozali, 2013), "Uji t statistik pada dasarnya menunjukkan seberapa jauh pengaruh satu variabel independen terhadap variabel dependen dengan menganggap variabel lainnya konstan”.

Tabel . 7

Hasil Uji t

\section{Coefficients $^{\mathrm{a}}$}

\begin{tabular}{|c|c|c|c|c|c|c|}
\hline & \multirow[b]{2}{*}{ Model } & \multicolumn{2}{|c|}{ Unstandardized Coefficients } & \multirow{2}{*}{$\begin{array}{c}\text { Standardized } \\
\text { Coefficients } \\
\text { Beta }\end{array}$} & \multirow[b]{2}{*}{$\mathrm{t}$} & \multirow[b]{2}{*}{ Sig. } \\
\hline & & B & Std. Error & & & \\
\hline \multirow[t]{3}{*}{1} & (Constant) & 5.643 & 3.312 & & 1.704 & .091 \\
\hline & Kualitas Produk & .641 & .071 & .638 & 8.962 & .000 \\
\hline & Promosi & .331 & .119 & .197 & 2.773 & .006 \\
\hline
\end{tabular}

a. Dependent Variable: Keputusan Pembelian

Sumber: Hasil Penelitian, 2018 (data diolah) 
Nilai t tabel IV.4 untuk probabilitas 0,05 pada df (penyebut) $=\mathrm{n}-\mathrm{k}$ maka $\mathrm{df}$ (penyebut) $=128-3=125$, derajat bebas $(\mathrm{df})=125$ adalah sebesar 1,97912. Pada Tabel IV.4, hasil uji parsial diperoleh hasil sebagai berikut:

1. Nilai thitung untuk variabel kualitas produk (8.962) lebih besar dibandingkan dengan nilai $t$ tabel yang dilihat dari tabel probabilitas $\mathrm{t}(1,97912)$ atau nilai sig t untuk promosi $(0,000)$ lebih kecil dari $\alpha(0,05)$. Berdasarkan hasil yang diperoleh maka menolak Ho dan menerima $\mathrm{H}_{\mathrm{a}}$ untuk variabel kualitas produk Dengan demikian, secara parsial promosi berpengaruh positif dan signifikan terhadap keputusan pembelian. Hal ini memberi arti kualitas produk memberikan dampak pada keputusan pembelian.

2. Nilai t hitung untuk variabel promosi (2.773) lebih besar dibandingkan dengan nilai t tabel yang dilihat dari tabel probabilitas $\mathrm{t}(1,97912)$, atau nilai sig $\mathrm{t}$ untuk variabel kualitas produk $(0,000)$ lebih kecil dari $\alpha$ $(0,05)$. Berdasarkan hasil yang diperoleh maka menolak $\mathrm{H}_{0}$ dan menerima $\mathrm{H}_{\mathrm{a}}$ untuk variabel promosi. Dengan demikian, secara parsial promosi berpengaruh positif dan signifikan terhadap keputusan pembelian. Hal ini memberi arti bahwa promosi memberikan dampak pada keputusan pembelian.

\section{KESIMPULAN}

\section{Pengaruh Kualitas Produk Terhadap Keputusan Pembelian}

Hasil penelitian yang dilakukan penliti membuktikan bahwa adanya pengaruh promosi terhadap keputusan pembelian. Hal ini dapat dilihat dari hasil uji parsial (Uji-t) dimana nilai $t_{\text {hitung }}>t_{\text {tabel }}(8.962>1.979)$ dan nilai signifikansi $0,000<0,05$. Sehingga hasil penelitian menolak $\mathrm{H}_{0}$ dan menerima $\mathrm{H}_{\mathrm{a}}$.

Permasalahan kualitas produk di perusahaan adalah Retur yang meningkat di bulan September dikarenakan banyak produk sudah tidak layak konsumsi. Jumlah retur yang sering terjadi memperlihatkan bahwa dalam setiap bulan perusahaan belum mampu dalam memberikan produk yang berkualitas sesuai dengan harapan konsumen.

Dapat diberikan saran kepada perusahaan untuk meningkatkan kualitas produk yang ada dan benarbenar melakukan seleksi produk sebelum dikirim ke pelanggan untuk menghindari produk yang tidak bisa dikonsumsi oleh pelanggan. Hal ini juga sangat berguna untuk menghindarkan retur dari pelanggan.

\section{Pengaruh Promosi Terhadap Keputusan Pembelian}

Hasil penelitian yang dilakukan penliti membuktikan bahwa adanya pengaruh promosi terhadap keputusan pembelian. Hal ini dapat dilihat dari hasil uji parsial (Uji-t) dimana nilai $t_{\text {hitung }}>t_{\text {tabel }}(2.773>1.979)$ dan nilai signifikansi $0,000<0,05$. Sehingga hasil penelitian menolak $\mathrm{H}_{0}$ dan menerima $\mathrm{H}_{\mathrm{a}}$.

Permasalahan promosi di perusahaan adalah terlihat bahwa jumlah promosi yang dilakukan oleh perusahaan cukup sedikit. Jadwal kegiatan promosi yang sedikit tentu akan membuat sebuah kesulitan bagi perusahaan dalam memperkenalkan produk lebih luas kepada pelanggan. Promosi yang tidak dilakukan dengan rutin tentu akan menjadi sebuah masalah dalam memperluas jaringan pemasaran di perusahaan. 
Dapat diberikan saran kepada perusahaan untuk meningkatkan frekuensi promosi yang dilakukan agar produk lebih dikenal di perusahaan. Peningkatan frekuensi promosi akan memberikan pengenalan produk yang lebih baik kepada pelanggan dan agar pelanggan memiliki kepercayaan terhadap produk-produk yang ditawarkan oleh perusahaan.

\section{REFERENSI}

Ghozali, Imam 2005;Aplikasi Analisis Multivariate dengan program SPSS.Semarang : BP Universitas Diponegoro.

Gujarati. D. N. 1995. Basic Econometrics, Singapore :Mc Graw Hill Inc.

Kotler, Philip. 2009. Manajemen Pemasaran, Jakarta :Erlangga.Moh. Nazir. 2005. Metode Penelitian, Jakarta :Ghalia Indonesia.

Santoso, Singgih. 2002. SPSS Versi 16 Mengolah Data Statistik Secara Frofesional, Jakarta :Gramedia.

Santoso, Singgih. 2006. Menggunakan SPSS Untuk Statistik Non Parametrik, Jakarta : PT Alex Media Komputindo.

Sugiyono. 2008. Metode Penelitian Bisnis, Bandung : Alfabeta.

Sugiyono. 2010. Metode Penelitian Kuantitatif Kualitatif dan R\&D,Bandung: Alfabeta.

Sugiyono. 2004. Statistik Untuk Penelitian, Bandung : Alfabeta.

Supranto.2006. Pengukuran Tingkat Kepuasan Pelanggan Untuk Menaikkan Pangsa Pasar. Tesis. Jakarta.

Tjiptono. F. 2015. Total Service Quality, Yogyakarta: Rineka Cipta. 